\title{
Tanggung Jawab Negara terhadap Pencemaran dan Perusakan Lingkungan dari Kegiatan Wisata Alam
}

\author{
Andi Abu Dzar Nuzul, Kornelius Benuf \\ Fakultas Hukum Universitas Gadjah Mada \\ achaboa420@mail.ugm.ac.id
}

Submit: 14-08-2020; Review: 21-05-2021; Terbit: 10-06-2021

\begin{abstract}
Regulations related to natural tourism activities are still not implemented effectively, this is evidenced by the various problems in the area of natural tourism have not yet obtained concrete solution. The state, which should have played an important role both in policy formulation and in management practices, is still considered negligent from its responsibility. This research will specifically discuss how the interpretation of the principle of state responsibility in regulating natural tourism activities in Mount Rinjani National Park, Lombok, West Nusa Tenggara. How effective is the regulation of natural tourism activities in Indonesia at this time. What is the legal analysis regarding natural tourism activities in Indonesia. This research was conducted using empirical research methods with a qualitative approach, based on primary data obtained through field research. Based on the research results, it is known that the state has responsibility for all forms of human behavior and / or activities that have an impact on the environment. The condition of Mount Rinjani National Park (TNGR) is different from the expectations contained in Article 4 of Law No. 10 of 2009, it can be concluded that the policy is not running effectively.
\end{abstract}

\section{Keywords: State Responsibility, Damage, Environment, Nature Tourism.}

\begin{abstract}
Abstrak
Pengaturan terkait kegiatan wisata alam masih belum terlaksana secara efektif, hal tersebut dibuktikan dengan berbagai masalah yang ada pada kawasan objek wisata alam masih terus bermunculan dan belum mendapatkan solusi yang kongkret. Negara yang seharusnya mengambil peran penting baik dalam perumusan kebijakan maupun dalam praktik pengelolaan juga masih dianggap lalai dari tanggung jawabnya. Penelitian ini membahas secara khusus bagaimana interpretasi asas tanggung jawab negara dalam pengaturan terkait kegiatan wisata alam di Taman Nasional Gunung Rinjani, Lombok, Nusa Tenggara Barat. Bagaimana efektifitas pengaturan kegiatan wisata alam di Indonesia saat ini. Bagaimana analisis hukum mengenai kegiatan wisata alam di Indonesia. Penelitian ini dilakukan dengan menggunakan metode penelitian empiris dengan pendekatan kualitatif, didasarkan data primer yang diperoleh melalui penelitian lapangan. Berdasarkan hasil penelitian diketahui bahwa negara mempunyai tanggung jawab atas segala betuk perilaku dan/atau kegiatan manusia yang berdampak pada lingkungan hidup. Keadaan Taman Nasional Gunung Rinjani
\end{abstract}


(TNGR) berbeda dengan harapan yang termuat dalam Pasal 4 UU Nomor 10 Tahun 2009, maka dapat disimpulkan bahwa kebijakan tersebut tidak berjalan secara efektif.

\section{Kata Kunci: Tanggungjawab Negara, Kerusakan, Lingkungan, Wisata Alam.}

\section{Pendahuluan}

Era millennial saat ini, kegiatan wisata alam di Indonesia adalah salah satu kegiatan yang paling digemari oleh wisatawan dari berbagai daerah di Indonesia maupun mancanegara. Hal itu dibuktikan dengan terus bertambahnya jumlah pengunjung di berbagai tempat wisata yang ada di Indonesia. Berdasarkan data dari Balai Taman Nasional Gunung Rinjani (BTNGR) yang merupakan salah satu dari banyaknya tempat wisata alam di Indonesia, jumlah pengunjung/pendaki pada periode 14 Juni 2019 sampai 31 Desember 2019 Mencapai 17.171 Pengunjung, yang dimana jumlah wisatawan asing berjumlah 12.639 orang dan wisatawan lokal berjumlah 4.532 orang (Sudiyono, 2018). Meningkatnya minat pengunjung disebabkan oleh tingginya nilai estetika serta kekayaan alam (flora dan fauna) yang ada di kawasan TNGR.

Beberapa tulisan terkait penegakan hukum atas kegiatan wisata alam dan terkait tanggung jawab negara atas terjadinya pencemaran dan perusakan lingkungan, seperti Jurnal yang ditulis oleh Marcella Apriani Lawang dengan judul Penegakan Hukum Terhadap Pencemaran Dan Perusakan Lingkungan Objek Wisata Berdasarkan Undang-undang Nomor 10 Tahun 2009 berisikan tentang pentingnya pengawasan terhadap ancaman perusakan dan pencemaran lingkungan objek wisata bahari dalam upaya melestarikan objek wisata bahari dalam memberikan kontribusi terhadap pembangunan nasional dan pemberlakuan sanksi pidana sebagaimana diatur dalam UU No. 10 Tahun 2009 (Marcella Apriani Lawang, 2015).

Penelitian lainnya dilakukan oleh Basuki Antariska dengan judul 
Penegakan Hukum Pariwisata Di

DKI Jakarta Sebagai Destinasi

Pariwisata Internasional yang membahas terkait "tugas utama yang seharusnya dilaksanakan oleh pembuat kebijakan di suatu destinasi pariwisata adalah melakukan kegiatan "sadar wisata" yang melibatkan seluruh pemangku kepentingan. Berdasarkan penelitian tersebut diketahui bahwa pembatasan-pembatasan yang dilakukan hukum Pariwisata akan menjamin keuntungan yang berkelanjutan dalam pembangunan kepariwisataan, karena etika bisnis yang baik justru akan memberikan keuntungan yang berkelanjutan (Basuki Antariska, 2012).

Jurnal yang ditulis oleh Sang Ayu Ditapraja Adipatni berjudul Perlindungan Hukum Terhadap Wisatawan Yang Mendapat Perlakuan Diskriminatif yang memberi kesimpulan bahwa dikesampingkannya asas Lex specialis derogat legi generalis (aturan yang bersifat khusus mengesampingkan aturan yang bersifat umum) karena perlindungan hukum terhadap wisatawan yang mendapat perlakuan diskriminatif tidak diatur dalam Undang-Undang Kepariwisataan (Sang Ayu Ditapraja Adipatni, 2018). Namun, dari beberapa tulisan yang ada terkait penegakan hukum atas dampak lingkungan dari kegiatan pariwisata, tidak satupun ditemukan tulisan yang memfokuskan fungsionalisasi asas tanggung jawab negara (state responsibility) dalam pengaturan kegiatan wisata alam di Indonesia.

Pada jurnal yang ditulis oleh Maya Pattiwael dengan judul Konsep Pengembangan Ekowisata Berbasis Konservasi Di Kampung Malagufuk Kabupaten Sorong berisikan tentang dampak negatif dari kegiatan ekowisata terhadap hutan alam dapat diatasi dengan pemberdayaan masyarakat lokal dalam kegiatan ekowisata yang berbasis konservasi agar kelestarian sumber daya alam yang ada pada daerah tersebut dapat terus terjaga. Maya beranggapan bahwa ekowisata berbasis konservasi merupakan pengembangan ekowisata yang menitikberatkan pada pola wisata ramah lingkungan, dimana pengembangan ekowisata harus mampu memelihara, melindungi, dan 
bertanggung jawab terhadap kelestarian alam”. Selain itu, Maya juga mengemukakan pendapatnya bahwa persoalan yang paling mendasar terkait aksesibilitas menuju Kampung Malagufuk yang perlu mendapat perhatian serius dari Pemerintah Daerah agar pengembangan Kampung Malagufuk sebagai kawasan ekowisata dapat berjalan dengan baik. Salah satu kegiatan berupa penanaman bibit pohon juga menjadi pilihan yang baik sebagai bukti kepedulian masyarakat terhadap pelestarian sumber daya alam yang ada di Kampung Malagufuk (Maya Pattiwael, 2020).

Dhoni Yusra menuliskan jurnal yang berjudul Kebijakan Penentuan Kualitas Air Serta Sanksi Bagi Pelaku Pencemaran dan Tanggung Jawab Ngara Mengantisipasi Pencemaran Air. Dalam tulisan tersebut, Dhoni menyatakan bahwa Indonesia sebagai negara kepulauan yang lautnya meliputi dua pertiga wilayah nasionalnya, serta memiliki garis pantai terpanjang kedua di dunia dan juga dikenal dengan negara bahari memiliki tanggung jawab yang sangat besar untuk melindunginya. Dhoni juga sangat menekankan terkait untuk pengaturan hukum lingkungan di Indonesia harus bersifat terpadu dan komprehensif serta menerapkan berbagai prinsip hukum pencemaran lintas batas nasional dalam peraturan perundang-undangan yang diatur secara integratif. Tulisan ini juga mengharapkan adanya peran serta masyarakat dalam setiap gerak pembangunan nasional (Dhoni Yusra, 2006).

Jurnal dengan berjudul Pengembangan Taman Wisata Rekadena Di Kabupaten Kubu Raya yang ditulis oleh Hari Aprianto menyimpulkan bahwa berdasarkan analisis dan pembahasan yang telah dilakukan untuk mencapai tujuan dari perancangan pengembangan taman wisata Rekadena di kabupaten Kubu Raya dengan konsep penataan lansekap yang memberikan konsep petualangan adalah dengan melakukan analisis terhadap aspek lanskap dan aspek petualangan. Hari juga menyatakan bahwa penataan sistem peletakan zonasi kawasan wisata terhadap kenyamanan 
aksebilitas kawasan taman wisata dapat memberikan keselarasan dalam kawasan. Tulisan ini juga menyatakan kenyamanan visual didapatkan dengan melakukan pengaturan dan pemisahan jalur sirkulasi service yang dilalui oleh kendaraan service, jalur sirkulasi yang dilalui pejalan kaki dan jalur sirkulasi transportasi air yang akan digunakan oleh pengunjung dan pengelola yaitu dengan kawasan taman wisata, serta dengan melakukan pembentukan pola jalur perjalanan yang membentuk kenyamanan penanda kawasan sehingga mampu menarik minat pengunjung untuk datang, karena mampu memberikan rasa aman dan nyaman (Hari Aprianto, 2015).

Nilam Sari mengutip pendapat dari Fandeli, yang merupakan akademisi dari Fakultas Kehutanan UGM dan Akademisi dari Institut Teknologi Yogyakarta mengemukakan pendapatnya bahwa ekowisata (wisata alam) mempunyai pengertian suatu perjalanan wisata daerah yang masih alami, dimana ekowisata selalu menjaga kualitas, keutuhan dan kelestarian alam serta budaya dengan menjamin keberpihakan kepada masyarakat (Nilam Sari, 2008). Wisata alam lebih menarik minat seseorang karena terkait dengan kegemaran baru masyarakat kontemporer perkotaan yakni kegiatan berjalanjalan, hiking, menikmati lingkungan asalnya (Ignatia Gisela Barata, Andrian Dektisa, 2015).

Penelitian yang terkait tanggung jawab negara atas terjadinya pencemaran dan perusakan lingkungan pernah dilakukan oleh Sudi Fahmi, dalam penelitiannya yang berjudul "Asas Tanggung Jawab Negara Sebagai Dasar Pelaksanaan Perlindungan dan Pengelolaan Lingkungan Hidup". Penelitian tersebut menyimpulkan bahwa kedudukan asas tanggung jawab negara sebagai dasar pelaksanaan perlindungan dan pengelolaan lingkungan hidup mengandung arti: Negara menjamin pemanfaatan sumber daya alam yang akan memberikan manfaat yang sebesar-besarnya bagi kesejahteraan dan mutu hidup rakyat, baik generasi masa kini maupun generasi masa depan. Negara menjamin hak warga 
negara atas lingkungan hidup yang baik dan sehat. Negara mencegah dilakukannya kegiatan pemanfaatan sumber daya alam yang menimbulkan pencemaran dan/atau kerusakan lingkungan hidup (Sudi Fahmi, 2011).

Berdasarkan pada beberapa penelitian sebelumnya, penelitian ini berbeda dengan penelitian sebelumnya yang membahas permasalahan serupa, penelitian ini dibuat karena peneliti menganggap pengaturan terkait kegiatan wisata alam masih belum terlaksana secara efektif, hal tersebut dibuktikan dengan berbagai masalah yang ada pada kawasan objek wisata alam masih terus bermunculan dan belum mendapatkan solusi yang kongkret. Negara yang seharusnya mengambil peran penting baik dalam perumusan kebijakan maupun dalam praktek pengelolaan juga masih dianggap lalai dari tanggung jawabnya. Adapun yang akan dibahas dalam penelitian ini yaitu Bagaimana interpretasi asas tanggung jawab negara dalam pengaturan terkait kegiatan wisata alam di Taman Nasional Gunung Rinjani, Lombok,
Nusa Tenggara Barat; Bagaimana efektifitas pengaturan kegiatan wisata alam di Indonesia saat ini; Bagaimana analisis hukum mengenai kegiatan wisata alam di Indonesia berdasarkan Undang-Undang Nomor 10 Tahun 2009 tentang Kepariwisataan.

\section{Metode Penelitian}

Metode penelitian yang digunakan dalam penelitian ini adalah metode penelitian empiris dengan pendekatan yang digunakan dalam tulisan ini adalah pendekatan kualitatif (Mukti Fajar, 2017). Penelitian ini menjadikan Taman Nasional Gunung Rinjani (TNGR) yang terletak di pulau lombok, Nusa Tenggara Barat (NTB) sebagai objek sekaligus lokasi penelitian. Jenis data yang digunakan adalah data yang didapat dari lapangan berdasarkan observasi dan wawancara terhadap narasumber penelitian berdasarkan pertanyaan-pertanyaan yang berkaitan dengan permasalahan penelitian, pengamatan terhadap sampah yang dihasilkan oleh pengunjung yang diproyeksikan hingga 10 tahun ke depan, maupun 
pengumpulan dokumentasi gambar saat melakukan penelitian lapangan (Amirudin, 2012). Seluruh data yang berhasil dikumpulkan, selanjutnya diinventarisasi, diklasifikasi, dan dianalisis dengan menggunakan yuridis kualitatif, dengan langkahlangkah kategorisasi dan intepretasi" (Benuf \& Azhar, 2020). Analisis kualitatif tersebut dilakukan melalui penalaran berdasarkan logika untuk dapat menarik kesimpulan yang logis, sebelum disusun dalam bentuk sebuah karya ilmiah (Roni Hanitjo Soemitro, 1982). Dalam penelitian ini, digali data tentang beberapa dampak sosial yang dihasilkan oleh kegiatan wisata alam. Penelitian ini juga mendeskripsikan beberapa interpretasi asas tanggung jawab negara dari beberapa instrumen hukum yang ada di Indonesia dan akan diintegrasikan dengan instrumen hukum lingkungan.

Hasil dan Pembahasan

Interpretasi Asas Tanggung Jawab Negara dalam Pengaturan Terkait Kegiatan Wisata Alam Di Taman Nasional Gunung Rinjani, Lombok, Nusa Tenggara Barat
Pembahasan mengenai interpretasi asas tanggung jawab negara dalam pengaturan terkait kegiatan wisata alam di Taman Nasional Gunung Rinjani, Lombok, Nusa Tenggara Barat ini, menggunakan metode interpretasi Sistematis, Yang dimaksud dengan penafsiran sistematis, ialah suatu penafsiran yang menghubungkan pasal yang satu dengan pasal yang lain dalam suatu perundangundangan yang bersangkutan atau pada perundang-undangan hukum lainnya, atau membaca penjelasan suatu perundang-undangan, sehingga mengerti apa yang dimaksud (Juanda, 2016). Berangkat dari metode interpretasi sistematis tersebut, dengan mengutip pernyataan dari Koesnadi Hardjasoemantri yang mengatakan bahwa dengan tanggung jawab yang sedemikian dan persoalan lingkungan sudah memasuki sendisendi nasional, regional, dan internasional sebagaimana dinyatakan dalam Deklarasi Konferensi Stockholm 1972 yang direspon baik oleh Indonesia dengan menerapkan produk hukum yang 
berorientasi pada lingkungan (environment oriented law) dengan memberlakukan Undang-Undang Nomor 4 Tahun 1982 tentang Ketentuan-ketentuan Pokok Pengelolaan Lingkungan Hidup (Kristwan Genova Damanik, 2018). Penjelasan Pasal 2 Undang-Undang Nomor 32 Tahun 2009 tentang Perlindungan dan Pengelolaan Lingkungan Hidup menguraikan asas tanggung jawab negara meliputi: a) negara menjamin pemanfaatan sumber daya alam akan memberikan manfaat yang sebesar-besarnya bagi kesejahteraan dan mutu hidup rakyat, baik generasi masa kini maupun generasi masa depan; b) negara menjamin hak warga negara atas lingkungan hidup yang baik dan sehat; dan c) negara mencegah dilakukannya kegiatan pemanfaatan sumber daya alam yang menimbulkan pencemaran dan/atau kerusakan lingkungan hidup. Penjelasan tersebut menunjukkan bahwa negara mempunyai tanggung jawab atas segala bentuk perilaku dan/atau kegiatan manusia yang berdampak pada lingkungan hidup (Siombo, 2013).
Tanggungjawab negara terhadap lingkungan hidup didasarkan pada tujuan Negara Kesatuan Republik Indonesia (NKRI), yaitu melindungi segenap bangsa Indonesia dan seluruh tumpah darah Indonesia. Tujuan NKRI ini mengandung makna bahwa negara bertanggungjawab untuk melindungi seluruh masyarakat Indonesia dan melindungi seluruh wilayah NKRI (Soemarsono, 2017). Khusus perlindungan terhadap wilayah NKRI, Pemerintah juga memiliki tanggungjawab terhadap pemanfaatan setiap sumberdaya alam yang terkandung di dalam wilayah NKRI demi kepentingan dan kesejahteraan masyarakat Indonesia secara keseluruhan (Wibisana, 2013).

Kesejahteraan masyarakat Indonesia secara keseluruhan di sini tidak hanya di masa sekarang, namun juga di masa yang akan datang. Hal ini dikenal dengan pembangunan berkelanjutan. Dengan demikian, tanggungjawab negara dalam pengelolaan lingkungan adalah pengelolaan lingkungan yang berkelanjutan, dengan menjaga stabilitas berbagai kepentingan yaitu 
kepentingan ekonomi, kepentingan sosial dan kepentingan lingkungan hidup (Sari, 2019).

\section{Konsepsi Asas Tanggung Jawab pada Hukum Internasional}

Negara merupakan subjek hukum yang terpenting (par excelence) dibanding dengan subjeksubjek hukum internasional yang lainnya (Situngkir, 2018). Negara sebagai subjek hukum internasional dapat dimintakan tanggung jawab ketika suatu negara tidak melaksanakan kewajiban, telah melakukan tindakan-tindakan kelalaian yang melawan hukum. Negara berkewajiban untuk tidak menyalah gunakan kedaulatan itu sendiri, ketika suatu negara menyalahgunakan kedaulatannya, maka negara tersebut dapat diminta suatu pertanggungjawaban atas tindakan dan kelalaiannya (Dewa Gede Sudika Mangku, 2019).

Dalam Hukum Internasional, tanggung jawab negara diartikan sebagai kewajiban yang harus dilakukan oleh negara kepada negara lain berdasarkan perintah Hukum Internasional. Sederhananya, apabila negara tidak memenuhi suatu kewajiban yang disebabkan kepadanya berdasarkan Hukum Internasional, maka ia dapat dimintai pertanggungjawaban (Eka An Aqimuddin, 2012). Jika merujuk Dictionary of Law, asas tanggung jawab negara dianggap sebagai Obligation of a state to make reparation arising from a failure to comply with a legal obligation under International Law (Mardiyono, 2016). Dari rumusan tersebut tanggung jawab negara diartikan sebagai kewajiban untuk melakukan perbaikan atas kesalahan yang timbul ketika suatu negara tidak mematuhi kewajiban berdasarkan apa yang termuat dalam Hukum Internasional. Nalcolm N. Shaw menyebutkan ada 3 karakter pokok pertanggungjawaban negara, yaitu: 1) The existence of an international legal obligation in force as between two particular states; 2) There has occured an act or omission which violates that obligation and which is imputable to the state responsible; dan 3) That loss or damage has resulted from the unlawful act or omission. (Malcolm N. Shaw, 2008). 
Berbeda dengan konsep tanggung jawab negara pada Hukum Lingkungan, konsepsi tanggung jawab negara pada Hukum Internasional membahas mengenai tanggung jawab suatu negara dengan negara lain yang diadopsi dari pengertian tanggung jawab negara dalam lingkup Hukum Internasional (Sujatmoko, 2016). Konsepsi tanggungjawab negara pada hukum internasional menempatkan kepentingan negara lain atau kepentingan internasional sebagai objek yang harus dilindungi.

Tolak Ukur Efektif Atau Tidaknya Pengaturan Kegiatan Wisata Alam

Efektif atau tidaknya suatu kebijakan dapat dilihat dari tercapai atau tidaknya tujuan dibuatnya suatu kebijakan yang tercantum di dalamnya (Kornelius Benuf, Ery Agus Priyono, Siti Mahmudah, Siti Malikhatun Badriyah, Bagus Rahmanda, 2020). Berbicara mengenai efektivitas peraturan hukum, maka terkait dengan daya kerja peraturan hukum tersebut di tengah masyarakat. Faktor yang mempengaruhi efektivitas peraturan hukum di tengah masyarakat yaitu kaidah hukum atau peraturan perundang-undangan itu sendiri, petugas penegak hukum, sarana penegakan hukum dan kesadaran masyarakat (Diana, 2011).

Adapun tujuan dibuatnya Undang-Undang No. 10 Tahun 2009 tentang Kepariwisataan, yang ada pada Pasal 4 huruf e, yaitu melestarikan alam, lingkungan, dan sumber daya. Namun, UU Kepariwisataan sebenarnya menyebutkan ada beberapa tujuan yang termuat di dalam Pasal 4 Undang-undang Nomor 10 Tahun 2009 tentang Kepariwisataan.. Bertolak dari penjelasan di atas, dapat dikatakan bahwa dengan melihat kondisi yang ada saat ini di kawasan Taman Nasional Gunung Rinjani (TNGR) dan mencocokkannya dengan tujuan dibuatnya dari UU Kepariwisataan maka dapat diketahui efektivitas UU No. 10 Tahun 2009 Tentang Kepariwisataan. Jika kegiatan pariwisata yang ada di Taman Nasional Gunung Rinjani sudah sesuai dengan tujuan dibuatnya UU No. 10 Tahun 2009 maka dapat 
disimpulkan bahwa pengaturan terkait kegiatan pariwisata di Taman Nasional Gunung Rinjani sudah efektif. Sebaliknya, jika keadaan Taman Nasional Gunung Rinjani (TNGR) berbeda dengan harapan yang termuat dalam Pasal $4 \mathrm{UU}$ Nomor 10 Tahun 2009, maka dapat disimpulkan bahwa kebijakan tersebut tidak berjalan secara efektif.

\section{Pengaturan Tentang Wisata Alam}

Pasal 1 UU Nomor 10 Tahun 2009 tentang Kepariwisataan mendefinisikan Kepariwisataan sebagai keseluruhan kegiatan yang terkait dengan pariwisata dan bersifat multidimensi serta multidisiplin yang muncul sebagai wujud kebutuhan setiap orang dan negara serta interaksi antarwisatawan dan masyarakat setempat, sesama wisatawan, Pemerintah, Pemerintah Daerah, dan pengusaha. Adapun tujuan dari kepariwisataan yang termuat dalam Pasal 4 huruf e UU Nomor 10 Tahun 2009 adalah melestarikan alam, lingkungan, dan sumber daya. Selanjutnya pada prinsip penyelenggaraan kepariwisataan, Pasal 5 huruf d menyebutkan bahwa memelihara kelestarian alam dan lingkungan hidup. Pada BAB VII UU tentang hak, kewajiban, dan larangan dalam kegiatan kepariwisataan yang dimana Pasal-pasal dalam bab tersebut menjadikan Pemerintah, Pemerintah Daerah, dan setiap orang baik itu wisatawan, masyarakat sekitar, maupun pelaku usaha yang ada pada kawasan pariwisata sebagai sasaran utama. Hanya saja pada BAB XIV tentang Sanksi Administratif dan BAB XV tentang Ketentuan Pidana hanya menjadikan wisatawan dan pengusaha pariwisata sebagai sasaran utama, padahal BAB VII UU ini juga telah menguraikan kewajiban terhadap Pemerintah dan Pemerintah Daerah yang semestinya juga mempunyai sanksi baik administratif maupun pidana apabila telah menyalahi kewajiban sesuai dengan yang diatur UU Nomor 10 Tahun 2009 tentang Kepariwisataan. Wisata alam yang terdapat di Indonesia bisa dibagi menjadi dua yaitu wisata flora dan fauna (Rahma, 2020) .

\section{Kondisi Taman Nasional Gunung Rinjani (TNGR) Saat Ini}


Dilansir dari wabsite Balai Gunung Rinjani dan Asuransi belum Taman Nasional Gunung Rinjani (BTNGR), Pada hari Selasa, 15 Oktober 2019 pukul 14.00 WITA, Petugas Resort Sembalun mendapatkan informasi via telepon dari masyarakat a.n Irjan (30) warga Dusun Bawak Nao, Desa Sajang, Kec. Sembalun bahwa telah melihat hotspot/titik api yang diperkirakan berada di lokasi sebelah Barat sungai Kokoq Putih dan di bagian Barat Pos II Sembalun. Luas areal yang terbakar diperkirakan sekitar $+60 \mathrm{Ha}$. Vegetasi terbakar yang dapat diidentifikasi berupa rumput, alangalang, perdu, pohon cemara gunung, pohon bak-bakan, dan lain-lain" (Administrator Balai Taman Nasional Gunung Rinjani, 2020). Permasalahan pada kawasan TNGR kembali disebutkan pada rapat yang dipimpin oleh kepala Balai Taman Nasional Gunung Rinjani dan Kepala Dinas Pariwisata NTB bahwa hal-hal yang harus menjadi evaluasi dalam wisata pendakian Gunung Rinjani yaitu, masih terdapat permasalahan dalam penggunaan aplikasi e-Rinjani untuk registrasi pendakian Gunung Rinjani, penerapan SOP Pendakian optimal dan seragam serta belum tersosialisasikan dengan baik kepada semua pihak, ketersediaan sarana dan prasarana wisata pendakian masih kurang serta fungsi sarana prasarana yang ada belum optimal, masih terdapat pelanggaran pada kegiatan wisata pendakian Gunung Rinjani seperti pendaki ilegal dan keberadaan ojek di jalur pendakian (Rinjani, 2020).

\section{Kegiatan pada kawasan TNGR}

Pada kawasan Taman Nasional Gunung Rinjani, masih terlihat banyaknya ojek di jalur pendakian. Keberadaan ojek tersebut membuat kikisan pada tanah kawasan gunung yang jika terus menerus dilakukan akan membentuk sungai kecil yang lama kelamaan akan melebar dan dalam akibat terkikis oleh air hujan maupun air dari kawasan yang lebih tinggi. Sampah yang ada di beberapa titik juga membuktikan kurangnya kepedulian masyarakat akan kelestarian lingkungan hidup khususnya kawasan TNGR yang masih minim. Kebakaran yang terjadi pada beberapa bulan 
sebelumnya juga menambah bukti kelalaian dari ulah manusia yang tidak bertanggung jawab. Solusi pembatasan kuota pendaki di gunung Rinjani masih dirasa belum efektif apabila tidak mendapat dukungan secara penuh dari masyarakat sekitar yang masih meloloskan pendaki yang berkunjung hanya sebatas rekreasi. Selain itu, penutupan Gunung Rinjani untuk pendaki selama beberapa bulan juga tidak memberikan hasil yang maksimal apabila tidak dibarengi dengan pembersihan pada jalur dan beberapa titik yang masih "dihuni" oleh sampah pengunjung. Pemberian edukasi terkait pentingnya menjaga kelestarian lingkungan pada masyarakat sekitar dan pengunjung TNGR juga penting agar keserasian dan keseimbangan ekosistem tetap terjaga sebagaimana mestinya.

\section{Simpulan}

Asas tanggung jawab negara, mengandung pengertian bahwa pembuat kebijakan seharusnya menambahkan 1 (satu) poin penting sehingga mampu membuat makna dari asas tanggung jawab negara menjadi lebih dalam dan mampu menjelaskan seperti apa bentuk pertanggungjawaban dari negara terhadap lingkungan hidup. Selain penambahan poin pada Penjelasan Pasal 2 UUPPLH, penambahan pasal pada UU Nomor 10 Tahun 2009 juga perlu dilakukan, khususnya pada BAB XIV tentang Sanksi Administratif dan BAB XV tentang Ketentuan Pidana yang masih terkesan mengenyampingkan asas tanggung jawab negara. Hal tersebut dibuktikan dengan tidak adanya pasal yang memberikan ketegasan terhadap sanksi yang dapat menjerat negara dalam hal ini Pemerintah dan Pemerintah Daerah apabila ditemukan kelalaian atau kesalahan atas penyimpangan dari kewajiban yang sudah ditegaskan pada BAB VII UU tentang Hak, Kewajiban, dan Larangan dalam kegiatan kepariwisataan. Kekosongan hukum dalam suatu peraturan perundangundangan akan menyebabkan kebingungan pada praktik penegakan hukum oleh aparatur negara dalam menjalankan tugas mereka sebagai penegak hukum. 
Makna dari asas tanggung jawab negara yang dimaksud disini yaitu "Negara turut andil dalam proses pemulihan atas lingkungan hidup yang mengalami pencemaran dan/atau kerusakan”. Dimasukkannya poin tersebut dalam penjelasan Pasal 2 UUPPLH terhadap asas tanggung jawab negara akan menambah tekanan pada negara dalam melakukan proses pemulihan lingkungan yang mengalami pencemaran dan/atau kerusakan. Poin ini juga dimaksudkan untuk memberikan kewajiban kepada negara agar terus melakukan kontrol terhadap pihak yang melakukan pencemaran dan/atau pengrusakan lingkungan hidup seperti korporasi (corporate) dalam melakukan proses pemulihan fungsi lingkungan hidup. Pemulihan fungsi lingkungan harus lebih dikedepankan dibanding menghukum pelaku pencemaran dan/atau pengrusakan dengan pidana penjara atau kurungan. Sanksi pidana hendaknya baru dimanfaatkan terhadap tindak pidana lingkungan apabila terdapat ketidakefektifan sanksi hukum administrasi, hukum perdata, dan alternatif penyelesaian sengketa di luar pengadilan. Dalam hukum pidana, hal ini dikenal dengan asas subsidaritas atau "ultima ratio principle" atau asas "ultimum remidium" atau "last resort" atau merupakan upaya terakhir.

\section{Daftar Pustaka}

\section{Buku}

Amirudin, Z. A. 2012, Pengantar Metode Penelitian Hukum, Jakarta : Raja Grafindo Persada.

Antariksa, Basuki. 2012, Penegakan Hukum Pariwisata Di DKI Jakarta Sebagai Destinasi Pariwisata Internasional. Pesona Indonesia, kemenpar.go.id

Fajar, Mukti Y. A. 2017, Dualisme Penelitian Hukum Normatif dan Empiris, Pustaka Pelajar.

Shaw, Malcolm N. 2008, International Law (6th ed.), Cambridge University Press.

Soemitro, Roni Hanitjo. 1982, Metode Penelitian Hukum dan Jurimetri, Jakarta : Ghalia Indonesia.

Sudiyono. 2018, Standard Operasional Prosedur Pendakian Taman Nasional Gunung Rinjani. Balai Taman Nasional Gunung Rinjani. 


\section{Jurnal}

Adipatni, Sang Ayu Ditapraja. 2018, Perlindungan Hukum Terhadap Wisatawan Yang Mendapat Perlakuan Diskriminatif. Jurnal Magister Hukum Udayana (Udayana Master Law Journal), 7 (1) : 122-132.

Aprianto, Hari. 2015, Pengembangan Taman Wisata Rekadena Di Kabupaten Kubu Raya. Jurnal Online Mahasiswa Arsitektur Universitas Tanjungpura, 3 (2) : 264277.

Barata, Ignatia Gisela, Andrian Dektisa, B. D. A. 2015, Perancangan Destination Branding Wisata Alam Kabupaten Karanganyar, Jawa Tengah. Jurnal DKV Adiwarna, 6 (1) : 1-11.

Benuf, K., \& Azhar, M. 2020, Metodologi Penelitian Hukum sebagai Instrumen Mengurai Permasalahan Hukum Kontemporer. Gema Keadilan, 7 (1) : 20-33.

Benuf, Kornelius, Ery Agus Priyono, Siti Mahmudah, Siti Malikhatun Badriyah, Bagus Rahmanda, A. S. 2020. Efektifitas Pengaturan dan Pengawasan Bisnis Financial Technology (Peer to Peer Lending) di Indonesia. Pandecta: Jurnal Penelitian Ilmu Hukum (Research Law Journal), 15 (2) : 210-230.
Damanik, Kristwan Genova. 2018, Implementasi Asas Tanggung Jawab Negara Sebagai Bentuk Perlindungan Hukum Terhadap Kerusakan Terumbu Karang (Studi Kasus Kecelakaan Kapal MV. Caledonian Sky Di Raja Ampat, Law Review, 8 (3) : 250-271.

Diana, L. 2011, Penyakit Sosial dan Efektifitas Hukum di Indonesia. Jurnal Ilmu Hukum, 2 (1) : 168-178.

Fahmi, Sudi. 2011, Asas Tanggung Jawab Negara Sebagai Dasar Pelaksanaan Perlindungan dan Pengelolaan Lingkungan Hidup. Jurnal Hukum Ius Quia Iustum, 18 (2) : 212228.

Juanda, E. 2016, Konstruksi Hukum Dan Metode Interpretasi Hukum. Jurnal Ilmiah Galuh Justisi, 4 (2) : 154 166.

Lawang, Marcella Apriani. 2015, Penegakan Hukum Terhadap Pencemaran Dan Perusakan Lingkungan Objek Wisata Berdasarkan Undang-undang Nomor 10 Tahun 2009, Lex Crimen, 4 (7) : 58-66.

Mangku, Dewa Gede Sudika, I. K. R. 2019, Tanggung Jawab Negara terhadap Penembakan Pesawat 
MH17 berdasarkan Hukum Internasional. Pandecta: Jurnal Penelitian Ilmu Hukum (Research Law Journal), 14 (1) : 25-33.

Mardiyono. 2016, Tanggung Jawab Negara dan Mekanisme Penyelesaian Extrajudicial Killings 1965. Refleksi Hukum, 1 (1) : 29-44.

Pattiwael, Maya. 2020, Konsep Pengembangan Ekowisata Berbasis Konservasi Di Kampung Malagufuk Kabupaten Sorong. $J$ DEPACE (Journal of Dedication to Papua Community), 1 (1) : 42-54.

Rahma, A. A. 2020, Potensi Sumber Daya Alam dalam Mengembangkan Sektor Pariwisata di Indonesia. Jurnal Nasional Pariwisata, $12(1): 1-8$.

Sari, Nilam. 2008, Peluang Pengembangan Ekowisata Kawasan Wisata Alam Senkima Di Taman Nasional Kutai. Jurnal Analisis Kebijakan Kehutanan, 5 (3) : 153-164.

Sari, D. A. A. 2019, Integrasi Tata Kelola Kebijakan Pembangunan Kelautan Berkelanjutan. Jurnal Rechts Vinding: Media Pembinaan Hukum Nasional, 8 (2) : 147-202.

Siombo, M. R. 2013, Arah Politik Hukum Lingkungan Di
Indonesia. MasalahMasalah Hukum, 42 (3) : 381-389. https://doi.org/10.14710/m mh.42.3.2013.381-389

Situngkir, D. A. 2018, Terikatnya Negara Dalam Perjanjian Internasional. Refleksi Hukum Jurnal Ilmu Hukum, 2 (2) : 167-180.

Soemarsono, M. 2017, Negara Hukum Indonesia Ditinjau Dari Sudut Teori Tujuan Negara. Jurnal Hukum Dan Pembangunan, 37 (2) : 300322.

Sujatmoko, A. 2016, Hak Atas Pemulihan Korban Pelanggaran Berat HAM Di Indonesia Dan Kaitannya Dengan Prinsip Tanggung Jawab Negara Dalam Hukum Internasional. Padjadjaran Journal of Law, 3 (2) : 330-350.

Wibisana, A. G. 2013, Pembangunan Berkelanjutan: Status Hukum dan Pemaknaannya. Jurnal Hukum \& Pembangunan, 43(1) : 5490. https://doi.org/10.21143/jhp. vol43.no1.1503

Yusra, Dhoni. 2006, Kebijakan Penentuan Kualitas Air Serta Sanksi Bagi Pelaku Pencemaran dan Tanggung Jawab Negara Mengantisipasi Pencemaran Air. Lex Jurnalica, 4 (1) : 39-45. 
Peraturan Perundang-undangan:

Undang-undang Dasar Negara Republik Indonesia Tahun 1945

Undang-undang Nomor 5 Tahun 1990 tentang Konservasi Sumber Daya Alam Hayati dan Ekosistemnya

Undang-undang Nomor 10 Tahun 2009 tentang

Kepariwisataan

Undang-undang No. 32 Tahun 2009 tentang Perlindungan dan Pengelolaan Lingkungan Hidup

\section{Website}

Administrator Balai Taman Nasional Gunung Rinjani. 2020, Kebakaran Hutan Di Jalur Pendakian Sembalun. Www.Tnrinjani.Net.

https://www.tnrinjani.net/be rita-209-kebakaran-hutan-

di-jalur-pendakiansembalun.html

Aqimuddin, Eka An. 2012, Tanggung Jawab Negara Terhadap Tindak Pidana Internasional. Negara Hukum.

https://www.negarahukum.c om/hukum/tanggung-jawabnegara-terhadap-tindakpidana-internasional.html

Rinjani, A. B. T. N. G. 2020, Evaluasi Wisata Pendakian Gunung Rinjani dan Pembahasan Rencana Penutupan Rutin Jalur Pendakian.

Www.Tnrinjani.Net. https://www.tnrinjani.net/be rita-225-evaluasi-wisatapendakian-gunung-rinjanidan-pembahasan-rencanapenutupan-rutin-jalurpendakian-.html. pada 29 Januari 2020. 